\title{
Anaphylaxis- don't forget lupin!
}

\author{
M Makatsori, A Cappella, R McKenzie, I Skypala \\ From Food Allergy and Anaphylaxis Meeting (FAAM 2013) \\ Nice, France. 7-9 February 2013
}

\section{Background}

Lupin is a decorative flower found in gardens around the world. It is a member of the legume family and in recent years, flour produced from its seeds has been increasingly used in food manufacturing, especially in breads, baked products and confectionery. Within a similar timeframe, lupin allergy has emerged as a major problem in European countries, with more cases also now appearing in the United Kingdom.

\section{Methods}

A 46 year old female with a history of asthma and seasonal allergic rhinitis was referred to our Food Allergy clinic. In the previous 2 years, she suffered two episodes of anaphylaxis without being able to identify the cause. The first anaphylactic episode occurred after eating a crab canapé. The other, after eating duck pâté, beef with vegetables and a fruit tart. After eating this meal, she developed a sensation of throat tightness, nausea and felt unwell. Twenty minutes later, she went on to develop wheeze and stridor, generalised pruritus, erythema, vomiting and diarrhoea. She has had milder symptoms after eating lobster chowder and mussels in Belgium and also with chocolate and toffee. She has been avoiding shellfish since the reaction. She was also avoiding peanuts as she was found to have a positive specific IgE test in the general allergy clinic.

\section{Results}

Total IgE was $159 \mathrm{iu} / \mathrm{ml}$. Specific IgE test to lobster, mussel, shrimp, fish, lipid-transfer protein, tree nuts and various legumes were negative. Specific IgE to peanut was 1.02iu/ml. Ara h 1, 3, 8 and 9 were negative while ara h2 was $1.74 \mathrm{iu} / \mathrm{ml}$. Skin prick testing (SPT) to peanut reagent, raw peanut and roasted peanut were negative. SPT to lupin flour was $25 \mathrm{~mm}$ and specific IgE $42 \mathrm{iu} / \mathrm{ml}$. Soy flour was $4 \mathrm{~mm}$. She has been eating soy and tolerates other legumes. SPT to tragacanth gum, a legume that she was using in sugar flower making was negative.

Allergy Department, Royal Brompton Hospital, London, UK

\section{Conclusion}

The strongly positive SPT and specific IgE tests to lupin, in conjunction with this being the common ingredient across the foods our patient reacted to, suggest lupin as the cause of these reactions. It is important for clinicians to consider lupin as a potential cause of unexplained foodrelated allergic reactions, as its use has now become widespread throughout Europe. Furthermore, cross-reactivity to peanut should be clarified with challenge testing. Of note, our patient had been using a facial anti-wrinkle cream that contained white lupin seed extract for over 7 years. This may represent an additional route of sensitisation.

\section{Disclosure of interest}

None declared.

Published: 25 July 2013

doi:10.1186/2045-7022-3-S3-P158

Cite this article as: Makatsori et al:: Anaphylaxis- don't forget lupin!. Clinical and Translational Allergy 2013 3(Suppl 3):P158.

Submit your next manuscript to BioMed Central and take full advantage of:

- Convenient online submission

- Thorough peer review

- No space constraints or color figure charges

- Immediate publication on acceptance

- Inclusion in PubMed, CAS, Scopus and Google Scholar

- Research which is freely available for redistribution

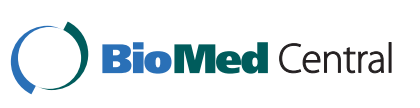

(c) 2013 Makatsori et al; licensee BioMed Central Ltd. This is an Open Access article distributed under the terms of the Creative Commons Attribution License (http://creativecommons.org/licenses/by/2.0), which permits unrestricted use, distribution, and reproduction in any medium, provided the original work is properly cited. 